\title{
Remarks upon Interlibrary Loans Mid-2oth Century Style
}

Dr. David is director of libraries, University of Pennsylvania.

$\mathrm{W}$

HEN OUR CHAIRMAN asked me to speak on this occasion she conditioned me for the reception of her request by saying very flattering things about the generosity of the interlibrary lending policy of the library over which I have the honor to preside, and then she went on to disarm me still further by speaking about the "liberalizing effect" upon interlibrary loan policy of the presence of a union library catalog - the Philadelphia Union Catalogue being a favorite brain child of mine. In later correspondence she formulated her thesis more precisely by saying: "My point is that the presence of a union catalog not only makes books easy to locate-it puts libraries in a lending frame of mind."

Now, gratified as I am to have the beneficient influence of a union library catalog rated so highly, I am not certain that Miss Stone's thesis is entirely sound. By making it easy to locate books in neighboring libraries a union catalog undoubtedly facilitates interlibrary loans. On this point there are Philadelphia statistics, though they are not as recent as one could wish. In I940 H. Glenn Brown, then head of the reference department in the University of Pennsylvania Library, published a survey of tools used in the location of items for interlibrary loan. In this it appeared that during the three years between the founding of the Philadelphia

\footnotetext{
1 Paper presented at the meeting of the College Libraries Section, A.C.R.L., Jan. 21, 1949, Chicago.
}

Union Catalogue and 1939 the use of our L.C. Depository Catalog decreased from 24 to 17 per cent and consultation of the national Union Catalog in Washington decreased from $3 \mathrm{I}$ to $2 \mathrm{I}$ per cent, while the Philadelphia Union Catalogue, which was not yet in operation in 1936, was by I 939 supplying 28 per cent of all successful locations. During the same period our inability to provide any locations decreased from 27 to 15 per cent. ${ }^{2}$ There is then no doubt of the influence of a local union library catalog upon interlibrary loans. Does it have any real influence on a lending frame of mind? I hope so, but I have had experiences with some librarians and library trustees which would seem to justify a doubt upon this point. I would, therefore, sound a note of caution and suggest the possibility that instead of a local or regional union catalog producing a lending frame of mind, it may be that the presence of an enlightened cooperative community spirit, a lending frame of mind, may itself have been an influence in the achievement of a successful union library catalog. Whichever has priority, we can at least agree that the area in which I have the fortune to reside, has over the last dozen years or so developed a remarkable and fruitful spirit of cooperation and mutual assistance among its numerous libraries, and that one of the most useful ways in which this spirit has manifested itself has been in an active traffic in interlibrary loans.

\footnotetext{
"Brown, H. Glenn. "Union Catalogs and Interlibrary Loan." College and Research Libraries $1: 336$. 339, September 1940.
} 
This is a subject of great interest and importance, and it seems to me to merit further discussion in the light of present day conditions.

The most arresting facts about interlibrary loans when they are looked at by the administrator of a large research library are their volume and their cost.

The practice of interlibrary loans in this country began in the late I9th century when a few of the larger research libraries began to lend to each other occasional volumes which were needed to accommodate scholars who would otherwise have had to travel considerable distances in order to consult them. For a good many years no library was called upon to lend more than a few score volumes a year and the practice was surely beyond criticism. It had so much to recommend it that it inevitably grew. Libraries gradually became less exacting in their requirements, professors and students having need of such service, more demanding; and so the practice has grown to its present proportions, extending throughout our American library system and resorted to by libraries of all descriptions. There would seem to be every indication that if the burden can be successfully carried, the volume of interlibrary lending will go on steadily increasing.

To illustrate current practice in some detail, let me turn to the experience of the University of Pennsylvania Library. During the year ending June 30, I948, we borrowed 1042 items and loaned 1862 . During the month of November we borrowed 148 items and loaned 196 . In other words we borrowed or loaned during the year an average of 12 books per staff working day, and during the month of

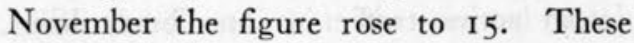
loans were handled in accordance with a code which in its essentials dates from
1917. While there has been considerable simplification and standardization since the early days when each loan was a special transaction and required the attention of the head librarian or his principal assistant, they still require a lot of correspondence, record keeping and other labor at both the professional and nonprofessional levels.

Let me list the principal details of what in our experience is now commonly regarded as minimum practice:

I. A form of application is filled out by the would-be individual borrower.

2. Necessary bibliographical work is performed by the borrowing library, the desired item is located and a letter is dispatched requesting the loan.

3. Some further bibliographical work is often performed by the lending library, and a letter or postcard is dispatched stating that the item is being sent.

4. Loan records are filed at the lending library (if this were the University of Pennsylvania, there would be records at both the reference and the circulation desks) and at the borrowing library (presumably the reference desk).

5. The book is wrapped, stamped and posted.

6. A receipt record is made by the borrowing library.

7. A letter or card is dispatched from the borrowing library stating that the book has been received.

8. The individual borrower is notified by postcard that the book has been received.

9. In due course records are changed at the borrowing library and the book is rewrapped, stamped and posted to the lending library.

ro. A card is posted to the lending library stating that the book is being returned.

II. A card is posted from the lending library stating that the volume has been received.

12. Records are cleared in both the borrowing and the lending institutions.

Bear in mind that these steps, which remind one somewhat of the handling of registered mail by the Post Office, are com- 
monly regarded as minimum. Many libraries keep fuller records and a good many loans are not ended with the comparatively simple transactions which I have described. Sometimes a loan cannot be made immediately and negotiations have to be renewed at a later date. Sometimes renewals have to be arranged. In addition, financial records as to postage, insurance, fees and the like are made by most institutions.

What has proved to be a disconcerting fact about these operations, at least to one administrator, is their cost. The subject seems not to have been adequately investigated and perhaps it is dangerous to investigate it closely. Nevertheless, I think we ought to try to face the facts. Wilson and Tauber $^{3}$ have recorded estimates, made some Io years ago, which approach $\$ 4.00$ per loan. A recent calculation made at the University of Pennsylvania places the figure considerably higher. It is roughly estimated that in connection with our interlibrary loan transactions in $1947-48$ ( 1042 borrowings plus 1862 lendings, or a total of 2904) we had total costs in staff salaries and other expenses of more than $\$ 3.50$ per transaction. If we assume that these transactions were costing the other libraries which joined us in them approximately the same amount, then it follows that the full cost of these loans was on the average above \$7.00-a figure which must surely make the interlibrary loan librarian and the responsible library administrator shudder!

Are we therefore to conclude that interlibrary loans are not worth the cost and ought to be abolished? No, certainly not, for their value is beyond all calculation. They supply the supreme satisfaction of librarianship which consists not in storing up books and preserving them for future generations (important as that is) but in

\footnotetext{
3 Wilson, Louis R, and Tauber, Maurice F. The University Library. Chicago, University of Chicago Press, 1945, p. 4 Ir.
}

making books or other records available to inquiring minds at the moment when they need to be consulted. They are more important than ordinary library loans because they supply a needed resource not otherwise available, or at least not otherwise available without still greater diffculty and expense. They prevent disastrous blocks to intellectual progress, and are decidedly worth their cost. On the other hand, with such costs as are currently apparent, it is surely incumbent upon librarians to do their utmost to cut these expenses to more manageable proportions.

Let us then examine our procedures more critically and inquire whether we are not needlessly encumbering this essential and growing activity with expensive practices which have largely outlived their usefulness. The analogy of other administrative histories suggests that we are. Of course I know that a good number of fairly rare and precious items are sometimes handled in interlibrary loan, and here I acknowledge that special precautions and formalities are necessary (we need to act like the Post Office in handling registered mail). I am now concerned not with these rarities but with the great majority of interlibrary loans. We have the same obligation to be careful and to guard against losses that we have in handling circulation within our own institutions. Have we a much greater obligation, and is it necessary to go to such lengths of correspondence and receipt and record as I have been outlining? If so, are we not in danger of making interlibrary loans so costly that they will become very nearly prohibitive and so defeat our highest purpose?

It has been almost a decade since for use in the Philadelphia area we adopted a special and somewhat simplified code of practice in order to handle loans in our locality a little more simply than the na- 
tional code seemed to rquire. It must be confessed, however, that the effect of our local code-except insofar as it may have acted as a direct encouragement to lending -has not been great.

More recently at the University of Pennsylvania, under the leadership of the assistant librarian, service division, we have attempted to go a step farther. Without abolishing local interlibrary loans, in the case of a number of neighboring institutions we have undertaken substituting (unless rarities are involved) ordinary direct loans. When our colleagues at the Academy of Natural Sciences need to use our books, we see no reason for requiring them to apply to the Academy librarian with a request that their wants be filled by a loan between institutions. We loan to them directly, the same as we do to our own faculty and students. As a rule we try to have such arrangements reciprocal, so that as borrowers we too may escape the formalities of interlibrary lending. Sometimes we meet with resistance when we ask for this privilege. If so we are not at all insistent. Our belief is that the awkward oneway traffic will not last indefinitely, that by degrees the leaven of our good example will work.

In spite of these changes we are still spending money and professional staff time on formal interlibrary loans, both local and at a distance, upon the scale which I have already indicated. Can anything properly be done here to cut red tape and to bring in less costly procedures?

Why do we keep two records of outgoing loans, one at our reference desk and one at circulation? Why do we deem it necessary to require receipts for books loaned to other libraries when, without any serious problems arising, we never require such receipts from individual direct borrowers? Why is it necessary, in the case of most items except rarities, to resort to the procedure of lending to libraries at all, so long as we have assurance that an individual borrower's own institution will accept responsibility for him.

Consider the case of an assistant professor of English at the University of Pennsylvania who requires an uncommon but not extremely valuable book which is not to be had in a Philadelphia library. $\mathrm{He}$ applies at the reference desk at the university, and an assistant locates a copy at Yale (often the would-be borrower knows of a convenient location). Our reference assistant then verifies the author, title, etc., and sends a request to Yale that the loan be made. Why should not the Yale Library lend the volume directly to our assistant professor, wrapping it and posting it, just as it would do, I suppose, in the case of a Yale faculty member, without covering letter, acknowledgement or any other formality. The fact that the University of Pennsylvania Library requested the loan is surely sufficient guarantee that we accept responsibility for the transaction. If our assistant professor should prove to be careless or dishonest, Yale would write to us and we would enforce prompt compliance with Yale's requirements or make full restitution in case of a loss, dealing with the offender directly or, if need be, taking the case to the head of the English department, or even to the provost of the university. Even though the borrower should prove to be an absolute scoundrel and escape with the book, its cost of say $\$ 5$ to $\$ 25$ would fall upon the University of Pennsylvania. The loss and the trouble would certainly be regrettable, but such an experience would be so rare as to be all but negligible. I am fully prepared, in the case of rare or fragile items, to have the usual more formal and expensive procedures continued. 
Assuming that the imaginary case is fairly typical and that Yale would agree to the simplified procedure suggested, the matter would stand something like this. We would have done a small amount of reference work and dispatched the request. At Yale the request would have gone directly to a nonprofessional assistant at the circulation desk who would have looked up the volume, brought it from the stack, made the usual charge and turned the volume over to a page for wrapping and posting. Had we merely enclosed a selfaddressed and numbered postcard with our request for the loan, its return to us through the mail would be a sufficient notice to us that the loan had been grantd and the transaction completed, except for the return of the volume to Yale. The individual borrower, upon finishing his use of the book, could be asked to use the wrapping materials from Yale for the return of the loan. For his guidance a printed form might be enclosed instructing him about various matters requiring his attention, such as sealing, insurance, return dates, etc. And a printed and gummed label might also be enclosed which would bring the volume back to Yale's circulation desk.

Without embarrassment we follow essentially this procedure at the University of Pennsylvania Library in making loans to individuals in the Philadelphia area. Telephone requests are honored at the circulation desk if the would-be borrower has a good reason for not coming to the library in person. Circulation assistants look up call numbers and the books are mailed out and received back without benefit of covering letters or acknowledgements. We lend to many individuals without formal tie to the university and encounter practically no difficulty.

I am suggesting that-as in the case of another essential library process, viz. cataloging - the costs have grown to such proportions that administrators are forced to try to find ways, without crippling the service, to reduce them. I am suggesting that while there will still be need for expert professional bibliographical service (which should be a function of the reference department of the borrowing library) particularly in connection with difficult items, it still may be possible in the case of a great many interlibrary loans for us to devise routine procedures, mainly at the nonprofessional level and handled largely through circulation departments. This would, in effect, change these transactions into something which we might have to call direct loans authorized by reciprocal interlibrary agreements, but which would make our service faster and less expensive.

In conclusion let me confess that I do not feel completely sure of the ground on which I stand. There are differences of opinion among experts in my own organization as $\mathrm{I}$ am sure there will be among experts in other libraries. I have never been an interlibrary loan librarian, and am very conscious that a top administrator turning a fishy eye on mounting costs may look foolish to a competent and expert technician in charge of operations in the plant. Moreover I have a clear impression that the issue raised has been inadequately studied. If my remarks should have the effect of stimulating investigation and discussion from which I may later hope to profit, I shall be well content. 